\title{
LOCAL HUMAN CAPITAL AND PRODUCTIVITY: AN ANALYSIS FOR THE SPANISH REGIONS
}

\author{
Esteban Sanromá (IEB, University of Barcelona) \\ Author to whom correspondence should be sent \\ IEB and Dept. of Econometrics, Avda. Diagonal 690, 08034 Barcelona (Spain). \\ Tel.+34+934034801. Fax: +34+934021821. E-mail: esanroma@ub.edu. \\ Raúl Ramos (AQR, University of Barcelona) \\ AQR and Dept. of Econometrics, Avda. Diagonal 690, 08034 Barcelona (Spain). \\ Tel. +34+934021984. Fax: +34+934021821. E-mail: rramos@ub.edu.
}




\section{LOCAL HUMAN CAPITAL AND PRODUCTIVITY: AN ANALYSIS FOR THE SPANISH REGIONS}

Abstract:

In this paper, we examine the relationship between the stock of human capital and productivity in the Spanish regions (NUTS III), and assess whether the transmission channel involves external economies. The empirical evidence points to a positive relationship between the two variables, although it cannot be explained in terms of the impact of exogenous local human capital external economies, but rather in terms of other demand factors.

Keywords: External economies, wages, human capital, regional labour markets

JEL codes: D62, J31, J24, R23

Revised version: April $3^{\text {rd }} 2006$ 


\section{$\underline{1 . \text { Introduction }}$}

Endogenous growth theory and new economic geography emphasise the importance of human capital in economic growth and localization decisions, both models inspiring a number of empirical studies in which the relationship between the stock of local human capital and the productivity of a given territory is tested. Such studies have also considered the possible presence of external economies associated with the local human capital stock and report a positive correlation between the latter and productivity. Two explanations have been provided for this relationship, both of which consider the influence in terms of demand factors. The first explanation is based on the presence of external economies associated with local human capital, while the second is based on the relationships of complementarity between various productive factors and, in particular, between human and physical capital.

In this paper, we use microdata to examine the relationship between the stock of human capital and productivity in the Spanish regions, and we seek to verify whether the transmission channel does indeed involve external economies. The main contributions of this paper are twofold. First, we consider a wider set of instruments than is usual in the literature to avoid the potential effects of the endogeneity of schooling. Only when appropriate instruments are applied can the empirical results concerning the relationship between human capital and productivity be properly interpreted. Second, while the role of human capital and external economies in promoting Spanish growth has been frequently highlighted (the Spanish case serving as model for developing countries, encouraged to follow a similar process of human capital accumulation), these earlier studies fail to analyse in sufficient regional detail to determine accurately the role of the external economies of human capital. Here, by contrast, we use microdata drawn from the Family Budget Survey (Encuesta de Presupuestos Familiares) for 1990-1991 and so are able to analyse the relationship between productivity and human capital at the provincial level (NUTS III).

The rest of the paper is structured as follows: in the next section, the previous literature, both theoretical and empirical, is briefly reviewed; the third section describes the statistical sources employed here, the econometric methodology adopted in the analysis and the empirical evidence obtained, followed by a summary of the main results. Section four presents our main conclusions. 


\section{Background}

Since long time ago, economic literature has highlighted the positive effects of education to the rest of workers in the same territory ${ }^{1}$. Human Capital Theory (Schultz, 1960; Becker, 1964) reinforced these ideas and investment in human capital as an individual and collective investment became widely diffused. The emergence of endogenous growth theory and the prominence given to externalities - especially those associated with human capital (Lucas, 1988) - have rekindled interest in analysis of the external effects of human capital as a possible explanation for the positive correlation between education and productivity. At the same time, the development of new economic geography and, in particular, the economy of cities (which highlighted the special nature of cities as centres for the exchange of ideas) raised awareness of the need to establish the territorial limits of the external effects (if they can be said to exist) of human capital.

In the 1990s, empirical research sought to describe the presence and magnitude of local human capital externalities in the United States. In all such studies, individual data were used and the territorial unit analysed was the urban area (defined as the Standard Metropolitan Statistical Area).

In a seminal contribution, Rauch (1993) proposed a spatial equilibrium model in which local human capital is considered as a territorial characteristic that has positive effects on productivity, but no effects as an amenity. In this model, when the average level of human capital in a territory increases, the resulting productivity improvement generates an increase in local wages. However, in order to maintain the spatial equilibrium of workers and firms, this wage increase has to be offset by an increase in housing costs. The estimation of the reduced form of the model, using hedonic equations for wages and rents taken from the 1980 US Census, offers clear evidence of the existence of local human capital externalities. The estimation of the model using 1990 US Census data confirmed these earlier findings and even pointed to a more significant role of human capital externalities (Almond, 1997). Adserà (2000), estimating local cost functions (wages plus land rents) with 1990 data, also confirmed the relevance of local human capital externalities on wages and rents. Dalmazzo and de Blasio (2005), using Italian data drawn from the Survey of Household Income and Wealth, also applied Rauch's model with similar results.

Other studies have tackled the problem by adopting a different methodological and empirical approach in an attempt at overcoming some of the limitations of the spatial equilibrium model. Moretti (1998) provided a more rigorous approximation using a two-stage approach. First, he estimated the average regional wage of the territory using Mincerian equations, in which the 
effects of individual variables can be considered and, second, he sought to explain this average wage in terms of the average level of education and experience in each region. He concluded that the positive relationship found in this second stage was related to the existence of external economies associated with local human capital. Using a similar model, but incorporating controls to take into account the effects of changing compulsory schooling laws, Acemoglu and Angrist (2001) failed to find any evidence of external economies of human capital when using US Census data for the period 1960 to 1980, but when using 1990 Census data, significant estimates of external returns of human capital were found.

Peri (1998) estimated the prices of physical labour, human capital and experience. These three price estimates then formed the endogenous variables that had to be explained by the average number of years of schooling, the average experience and the employment rate in the territory. His results also confirmed the positive correlation between the educative stock of the territory and the price of human capital. However, as it was not clear whether the local human capital was strictly exogenous, its effects could not be attributed to externalities. A similar conclusion was reached by Rudd (2000) following his analysis of the existence of human capital spillovers in state level US data from the Current Population Survey (1978 to 1991). He describes several tests in which he seeks to determine whether the positive relationship reported between the average state education and individual earnings reflects actual external effects to human capital accumulation. After controlling for time-invariant state fixed effects and other state characteristics, he concludes that this relationship probably reflects the fact that the average level of education in a state is a good proxy for other productive factors.

Thus, it remains essential to establish the economic reasons that underlie the empirical regularity detected between local human capital and a territory's productivity. Two explanations have been forwarded, both of which consider the influence of demand factors: The first explanation is based on the presence of external economies associated with local human capital, while the second involves the adoption of techniques that make an intensive use of factors that are complementary to human capital.

The first explanation - learning external economies - is concerned with the interactions between individuals living in a given territory. These interactions ensure that knowledge is shared and exchanged with a resulting improvement in the level of productivity of the territory. The profitability and productivity of these exchanges increase with rising levels of individual 
schooling. Thus, we can speak of human capital external economies in the territory (Lucas, 1988).

The second explanation is associated with imperfect matching and it relies on the assumption that in territories with the highest levels of human capital, firms will invest more in physical capital. In a random process during which firms hire their workers, the final result is not only an improvement in the labour productivity of qualified workers but also in that of those with lower qualifications. The latter group, in particular, benefit from having more physical capital than is strictly necessary, and their productivity (and wages) increase at a higher than proportional rate (Acemoglu, 1996). However, while this process can increase productivity and wages in a territory, it may also affect individuals' decisions regarding their level of schooling as well as the territory in which they choose to live. For example, areas with higher wages attract population or provide an incentive for the resident population to increase their educational level. This indicates that the human capital stock will not remain independent of a territory's wage level, nor will it be the case for external economies of the human capital on wages. In fact, productivity improvements are the result of the adoption of intensive techniques in physical and technological capital that are complementary to human capital (Acemoglu, 1998).

The objective of this paper is, therefore, two-fold: first, to determine whether or not there is a relationship between the average level of human capital in a territory and its productivity; and, second, if so, to investigate how this relationship correlates with the existence of external economies or, alternatively, with the adoption of new techniques.

\section{Empirical evidence for Spain}

Two of the main features of human capital accumulation in Spain between the 1960s and 1990s were the very low initial levels of qualification presented by the workforce and the very high growth rate in levels of schooling. Serrano (1999) reports that by the mid-1990s two-thirds of Spanish workers had completed secondary education. According to the Family Budget Survey (Encuesta de Presupuestos Familiares), the average number of schooling years increased from 6.03 in 1980 to 7.97 by 1990 . At the regional level, a similar pattern was observed, though the provinces with the lowest average levels of schooling at the beginning of the 1980s underwent greater improvements in their education. In fact, as Figure 1 shows, these provinces were able to close the gap markedly on the other provinces. Thus, while the coefficient of variation for the average provincial schooling level in 1980 was $15.83 \%$, this figure had fallen to $9.73 \%$ in 1990 . 


\section{FIGURE 1}

The role played by human capital in promoting Spanish economic growth has been stressed in a number of studies. However, these analysis either use aggregate data for the whole of the Spanish economy (de la Fuente, 1996 and Serrano, 1997) or they estimate convergence equations based on data for the Spanish regions at the NUTS II level (Comunidades Autónomas) (Gorostiaga, 1997, Serrano, 1999). Here, however, we work with micro data at the NUTS III territorial level (Provincias), being these two of the differential features of our work.

In fact, empirical evidence for human capital externalities in the Spanish provinces is particularly meagre. In an earlier study (Sanromá and Ramos, 1999a), we identified, however, the different types of external economies affecting the Spanish industrial sector using microdata. These results point to the empirical importance of external economies generated by human capital accumulation and the productive specialisation of the territory (intraindustrial Marshallian external economies). Building on this earlier study, here we provide evidence of the relationship between human capital and wages (productivity).

\section{$\underline{3.1 \text { Methodological approach }}$}

Our starting point is the model developed by Rauch (1993) for analysing the relationship between human capital and the productivity of cities. In so doing, he breaks the individual's wage in each city into three components: (1) individual factors (including age, gender, schooling and experience); (2) workplace characteristics (occupation, part-time employment) and (3) the specific city factors that might affect his/her productivity.

The relationships between the individual's wage and each of these factors are then summarised using the following semilogarithmic function, which according to Mincer (1974) is the most appropriate functional form:

$$
\ln W_{i j}=f\left(s_{i j}, x_{i j}, z_{i j}, \alpha_{j}\right)+u_{i j}
$$

where $\ln W_{i j}$ is the natural logarithm of the annual wage of individual $i$ who resides in province $j, s_{i j}$ is a measure of the individual's level of education (Table 2), $x_{i j}$ a measure of his/her experience and $z_{i j}$ includes other individual factors that might affect wages, including gender, part-time employment or 
workplace characteristics (such as the industry sector - Table 3 - or occupation - Table 4). $\alpha_{j}$ is a group of dummy variables that seek to approximate the other factors that might affect productivity in the territory $j$ once all other individual characteristics are controlled. Finally, $u_{i j}$ is a random error term following a normal distribution with zero mean and constant variance.

From Equation (1), it is now possible to obtain a measure of the average labour productivity in each territory. Then we can analyse the relationship between the average territorial productivity and the level of local human capital taking these $\alpha_{j}$ as an endogenous variable in a regression with the average level of education $\left(s c h_{j}\right)$ and the average experience $\left(\exp _{j}\right)$ at the territorial level considered as explanatory variables:

$$
\hat{\alpha}_{j}=f\left(\operatorname{sch}_{j}, \exp _{j}\right)
$$

Therefore, our methodological approximation involves estimating a wage equation using individual data to obtain estimates of the average territorial productivity (Equation 1) and, then introducing these estimates as the endogenous variable in a second equation (Equation 2) where the explanatory variables are the average level of education and experience of the province. The statistical sources are discussed in the following section.

\subsection{Statistical sources and definition of variables}

\subsubsection{Wages, individual and workplace characteristics}

The estimates presented here are based on data from the Family Budget Survey (Encuesta de Presupuestos Familiares) for the second quarter of 1990 to the first quarter of 1991, conducted by the INE (the Spanish Institute of Statistics). Although the primary purpose of this survey is to analyse the consumer expenditure of the Spanish families, it also provides information about wages, individual and workplace characteristics. The sample size of our study provides greater territorial detail than other databases of similar content.

Our data includes 16,949 individuals who declared annual positive incomes from paid employment in non-agricultural industries together with their corresponding details describing individual and workplace characteristics. 
Data from the Spanish Family Budget Survey allows us to control the territorial dimension at a provincial level - the territorial administrative unit corresponding to the NUTS-III level of classification. Although this territorial unit is not the most appropriate size for a study of this nature, it is sufficiently small to allow us to assume that the provinces approximate local labour markets. In common with most western countries, Spain presents geographical wage differences of considerable magnitude, with regions in the northeast of the peninsula (from Asturias to Catalonia) and in Madrid enjoying higher average wages than the rest. These areas contain the two most dynamic axes in the Spanish economy: the Mediterranean Arc and the Ebro axis. Indeed, comparatively, inter-regional wage differences in the Spanish labour market are very high. Simón and Russell (2004) have estimated the magnitude of wage differentials between the regions of several European countries using harmonised microdata from the European Structure of Earnings Survey 1995 and report that regional wage differentiation in Spain is three times that observed in Belgium, twice as great as that recorded in Italy but similar to figures reported for Britain.

Regarding the main explanatory causes of wage differences among the Spanish provinces, in two earlier works, we found that wage differences between the Spanish provinces cannot be accounted for by their unequal power of attraction in terms of climate, culture, education, health, or entertainment provisions. The only influence on wages seems to be price levels, which act to reduce the inequalities that would otherwise be generated in purchasing power. An unbalanced territorial distribution of unemployment has also been found to be a relevant factor (Sanromá and Ramos, 1999b). In Simón et al. (2006), we focused on the role of industry-level collective bargaining to explain inter-regional wage differentials in the Spanish labour market. In this case, we found that the influence of collective bargaining in generating regional wage differences was enhanced by the regional dimension of the system in the Spanish case, where sectoral agreements for territories at a level below that of the national level predominate. However, in these two earlier studies, we did not examine the role of human capital externalities.

\subsubsection{Provincial human capital}

In approximating the level of local human capital for each province, in line with Rauch (1993) we calculated (1) the average level of education in the province and (2) the average level of experience in the province using data from the available sample.

The first of these variables was constructed as the average number of years of schooling received by the workers in the sample. The descriptive statistics of this variable - the equivalence between the 
different levels of schooling used in the survey and the number of years of schooling for each worker - are shown in Table 1. As expected, there was a marked positive relationship between individual wages and schooling.

\section{TABLE 1}

The second variable was constructed as the average level of potential experience of the workers in the sample. Potential experience is defined, as is usual in the literature, as age minus years of schooling minus six.

\subsection{Results of the estimation procedure}

\section{$\underline{\text { 3.3.1. Basic results }}$}

The ordinary least squares (OLS) estimates for Equation 1 in which individual wages are related with individual and workplace characteristics and the average productivity of the territory are shown in Table 2. In this equation, the explanatory variables taken into consideration are similar to those included in an enlarged Mincer equation. All the individual variables included here to control for individual effects on wages were significant and presented the expected sign and magnitude. Specifically, the variables relating to individual schooling levels and potential experience (included in quadratic form) reveal the existence of a positive relationship between individual human capital and wages that is similar to the one reported in the literature. The model also includes dummy variables for the occupations to control for the effect of specific job characteristics - for example, fatigue or risk - and the various employment structures in the various provinces as regards wages. In general, our results can be considered satisfactory as approximately $40 \%$ of wage variance can be explained - a similar percentage figure to that recorded in other studies using individual data.

\section{TABLE 2}

Equation (2) analyses the relationship between productivity and the provincial level of human capital. The results obtained when estimating this equation by weighted least squares (using the standard error of the estimates of $\alpha_{j}$ in Equation 1) are shown in Table 3, Model 1. These results show evidence of a significant and positive relationship between territorial productivity and the local level of human capital. The coefficient associated with the average level of education is positive and significant at the usual levels, while the coefficient associated with the average level of 
experience is not significant. As Rauch (1993, p. 391) remarks, "It stands to reason that the probability that a meeting between agents/ideas in a SMSA will be productive is increased more by a year of SMSA average education than by a year of SMSA average experience, since a major of formal education is concerned with communication skills, i.e. reading, writing, and (to a lesser extent) oral presentation".

\section{TABLE 3}

\subsubsection{Selection bias}

Selection bias in the sample size was also considered on the understanding that territories with higher levels of human capital (and productivity) might attract workers with a higher level of education (in relative terms). Were this to be the case, the effect could be due to the selection of workers with higher productivity in territories with higher levels of human capital. For this reason, we reestimated the above model taking into consideration only those workers that had not changed their place of residence in the previous ten years ${ }^{2}$. The results (available from the authors on request) did not vary substantially from our previous findings. A possible explanation for this is that the proportion of migrants in our sample is only $2.31 \%$ of total workers. Although the number of internal migrations has been great in recent decades (approximately four million people from a total population of forty million between 1970 and 1990), qualified workers do not seem to have been responsible for many of these movements. In the early 1970s, most migrants were low-qualified workers moving from the agricultural sector to industrial areas, while in the first half of the 1980s, following rising levels of unemployment in industrial areas caused by the first and second oil crises, some of these migrants returned to their provinces of origin, where wages were lower (Ródenas, 1994). Taking this into account, and considering that the results were not substantially different, henceforth we use the total sample of workers.

\section{$\underline{\text { 3.3.3. Omitted variables }}$}

In analysing the correlation between average education and earnings we need to rule out the possibility of omitted variable bias. In order to ensure that the estimated coefficient of the provincial average level of schooling does not reflect the effects of an omitted factor, additional control variables at the provincial level need to be included. As Rudd (2000) stresses, the direct inclusion of a measure of per capita income would not be appropriate for two reasons: first, because "it comes close to regressing a dependent variable - the wage term in the earnings regression - on itself', and, 
second, because if schooling increases productivity and income at the provincial level, a collinearity problem will arise between both regressors. It is for these reasons that other control variables have been suggested in the literature.

First, a potential relationship exists between the economic magnitude of the territory being analysed and its productivity (agglomeration effects). The hypothesis is that the higher the number of workers in a territory, the greater their probability of establishing contacts with each other and, because of the higher intensity in the flow of information, the greater their average productivity will be. Moreover, in a large local labour market, the matching between workers and vacancies becomes more efficient and, as a result, the productivity of the territory increases (Ciccone and Hall, 1996). The economic magnitude of the province is proxied here by the number of workers employed in non-agricultural sectors in the province. ${ }^{3}$

Second, and owing to the existence of capital-skill complementarities, better-educated workers can be located in those regions with a higher level of physical capital per worker. In such cases, part of the contribution of physical capital to regional productivity can be captured by regional average education. ${ }^{4}$

Third, the positive relationship between regional human capital and wages might reflect the existence of a wage curve (i.e., a negative relationship between wages and regional unemployment, see Blanchflower and Oswald, 1994 and 2005). If individuals with higher schooling levels have, on average, lower unemployment rates, then it can be argued that regional schooling levels could be proxying (at least, partially) the unemployment rate (Rudd, 2000). ${ }^{5}$

If we did not consider the effects of these variables when estimating Equation (2), the validity of our estimates of the coefficient associated with human capital and its standard error might be affected (omission of relevant variables). For this reason, the specification of Equation (2) includes these explanatory variables so as to address these effects. The results obtained are shown in Models 2 to 5 in Table 3. The most significant result is that the average level of human capital remains positive and significant when these control variables are included. The coefficients associated with employment and physical capital stock are positive, although not significant. The unemployment rate is also significant with a coefficient of -0.05 , which is slightly lower than that reported for several countries in the meta-analysis: -0.07 (Nijkamp and Poot, 2005). 


\subsubsection{Exogeneity of human capital}

An additional econometric problem that needs to be faced in analysing the relationship between human capital and productivity is that of endogeneity. ${ }^{6}$ Here, our results show the existence of a positive and significant relationship between productivity and provincial human capital. In this context, the mechanism giving rise to this relationship has to be identified. As mentioned earlier, if provincial human capital is independent of productivity (and wages), then this effect will be related to the presence of external economies. In this sense, as Moretti $(1998$, p. 2) remarks, "Rauch's assumption that city average education is historically predetermined is problematic, if bettereducated workers tend to move to cities with higher wages". Territories that are more productive will be more attractive to qualified workers and individuals in these territories will have more incentives to study, as wages are high. If this is true, human capital will be endogenous and no external economy will be present.

The most appropriate method for avoiding the effects of the potential endogeneity of schooling is instrumental variable estimation. However, it is necessary to find a set of proper instruments (i.e, those that correlate with the variable of interest, but which at the same time do not correlate with the regressors under consideration) and, for this reason, the validity and relevance of any potential instruments must be tested "since their low quality may only lead to even larger biases in IV estimates than those produced by OLS method" (Halyna, 2004).

Various instruments related to the lagged regional demographic structure have been suggested in the literature. Following Dalmazzo and de Blasio (2005), we used the provincial share of residents under the age of five in 1981 and the provincial share of residents between the ages of five and ten in 1981. Because of the compulsory schooling system, the 1981 provincial demographic structure is closely related to 1991 provincial average levels of schooling but, at the same time, it is unlikely to correlate with regional labour markets during the 1990s.

Moreover, adopting a similar approach to that reported by Arkes (2003), we considered the unemployment rates for those aged 16 to 19 in 1981 in every region as a potential instrument of schooling. In the presence of a high unemployment rate, lower wages and fewer job opportunities reduce the opportunity costs of attending school and the average schooling level in the territory rises (probably extending beyond compulsory schooling). ${ }^{7}$ 
In order to test the validity of these instruments, we applied the set of diagnostic tests proposed by Baum et al. (2003). First, we performed two tests for the endogeneity of schooling: the WuHaussman F-statistic and the Durbin-Wu-Hausmann Chi-squared statistic. The null hypothesis of both tests is that schooling is exogenous and, if this is not rejected, then OLS is the most efficient estimation technique (in this case, the variance of the IV estimator will be larger). Second, in testing the relevance and validity of the potential instruments, it is important to verify as to whether they are correlated with the endogenous variable being considered and whether they are orthogonal to the error term. The first condition can be tested by examining the fit of a regression in which the endogenous variable is regressed on the full set of instruments. In this context, Baum et al. (2003) suggest testing the joint significance of the instruments and examining the partial $\mathrm{R}^{2}$ in this regression. In the case of an overidentified model (for which several instruments are available), the second condition can be tested using a Sargan type test with a null hypothesis of valid instruments. Here, we applied the Hansen (1982) $\mathrm{J}_{\text {test. }}{ }^{8}$ The results obtained from applying these tests are shown in Table 4. As it can be seen, the tests do not reject the hypothesis that human capital is exogenous.

\section{TABLE 4}

Our instrumental variable estimation results are shown in Model 5 in Table 3. Although the coefficient signs associated with the unemployment rate and the provincial level of human capital were as expected (negative and positive respectively), in both cases, they were only significant at the $10 \%$ level. This reduction in significance for the provincial level of human capital casts some doubt, therefore, on the existence of external economies.

\subsection{Extension of the results}

In the model shown in Equation 1, the coefficient associated with the effect of the number of years of schooling on individual wages is a constant across the provinces. However, as Rudd (2000) stresses, the effect of imposing a linear return to education across the regions needs to be assessed. We, therefore, re-estimated the model allowing the slope coefficient for the number of schooling years to vary over the 50 provinces. Specifically, interactions between schooling years and the provincial fixed effects were included in the Mincer earnings regression. The results obtained were

quite similar to those recorded in Table $3^{9}$ with the exception of the fact that the data reject the imposed restriction, i.e, that the return to education is constant across the regions. 
As above, the estimates of the provincial dummy variables in this model were used as endogenous variables in a second stage. Our results when applying these new data are shown in Table 5. It can be seen that the results for variables related to human capital externalities in Models 1 to 4 are very similar to our earlier findings. The main difference being that now positive and significant effects of employment (Model 2) and physical capital stock (Model 3) were recorded. The results in Model 4 also show a negative and significant effect (at the 10\% significance level) of the unemployment rate. In Models 5 and 6, two control variables - the employment and unemployment rates - were introduced simultaneously. In Model 5, the variable associated with the provincial level of human capital remained positive and significant, while a similar result was found in Model 6 where controls included the physical capital stock and unemployment rate. Note that employment and physical capital stock per worker were not included simultaneously because of problems of collinearity.

\section{TABLE 5}

As discussed earlier, a major obstacle to the accurate estimation of this model is the potential endogeneity of human capital. However, this problem might also extend to the employment variable, since territories with high productivity (and wages) might attract workers thereby reversing the previous causality relationship (size of the labour market $\rightarrow$ productivity). To offset this bias, we added other instruments to those already included for human capital (lagged demographic variables and lagged youth unemployment rate). These new instruments were related to the level of employment, though not to productivity. Specifically, we constructed an indicator of culture per capita (see annex 1) and a dummy variable that adopts a value of 1 if the province has a coast line and a value of 0 otherwise. These instruments seek to approximate the influence of quality-of-life factors on workers' location decisions and, thus, the possibility that areas with higher wages are those that attract a higher number of workers. The results of the standard validity tests (available from the authors on request) suggest that these instruments are adequate and that the null hypothesis of exogeneity is clearly rejected. When these instruments were used, provincial employment and the provincial average level of education were not significant.

Model 8 in Table 6 shows the results of applying instrumental variable procedures to the model where the unemployment rate and the physical capital stock are used as provincial control variables. The set of instruments used for the human capital variable are the same as those used in Model 5 of Table 3 (the provincial lagged demographic structure and the regional unemployment rate for young workers). When these instruments (again relevant and valid according to standard tests) were used, 
no evidence of human capital external economies was found. These results are similar to those obtained by Peri (1998) and Rudd (2000) but contradict the evidence found by Moretti (1998) and Dalmazzo and De Blasio (2005). In all these studies, a positive relationship between local human capital and regional productivity was found. However, the studies that apply instrumental variable techniques (Peri, 1998; Rudd, 2000) conclude that local human capital is not exogenous to the differences in local productivity levels, and, as a result, they reject the existence of human capital external economies.

If we return to the empirical evidence obtained here, our conclusion is that the positive relationship between the local level of education and the average productivity of the territory cannot be explained in terms of the impact of human capital externalities but rather it reflects other demandrelated effects. The most reasonable explanation is perhaps that forwarded by Acemoglu (1998): higher levels of human capital in a territory can attract technological investment if both factors are complementary, which in turn increases productivity levels and wages. Moreover, higher wage levels can attract more highly qualified workers and, as a result, the higher level of human capital will attract capital investment, which can feed back into wage levels. Therefore, it appears that the positive relationship is not caused by the presence of external economies of human capital.

\section{$\underline{\text { 4. Conclusions }}$}

In this paper, we have considered whether a relationship exists between the level of human capital and productivity in the Spanish provinces and, also, whether this relationship reflects the presence of external economies. A two-stage methodology has been applied: first, a Mincer equation was estimated using information from the Family Budget Survey (Encuesta de Presupuestos Familiares) for 1990-91 to approximate the average productivity of the Spanish provinces; second, these estimates of provincial productivity were taken as being endogenous in a regression against the level of provincial human capital. From this second regression, a positive relationship was found between the average productivity of the territory and the average level of education. However, when controlling for endogeneity, this relationship could not be accounted for in terms of the impact of external economies associated with human capital, but rather is due to other demand factors.

External economies derived from human capital, however, might well be more intense in much smaller geographical areas or even at the plant level. The evidence presented by Fu (2005) in his analysis of Massachusetts' census tracks and blocks suggested that human capital externalities are highly localized within microgeographic areas of the city. Were we to gain access to suitable 
statistics, a possible extension of our analysis might involve the use of data providing this depth of detail.

\section{$\underline{\text { 5. Acknowledgments }}$}

The authors wish to thank two anonymous referees for their suggestions. Esteban Sanromá gratefully acknowledges the support received from CICYT SEJ2004-05860/ECON and Raúl Ramos from CICYT SEJ2005-04348/ECON. The usual disclaimers apply.

\section{$\underline{\text { 6. Final notes }}$}

1 Although Adam Smith (1776, Book I, Chapter 10-1) highlighted the positive effects of education on productivity, Marshall was the first to argue that this effect could extend to other workers in the same territory. In his study of the "industrial district", Marshall (1890) describes technological spillovers resulting from the interaction between workers in the same district, thereby promoting learning and, in turn, increasing productivity.

2 This was the only information available in the database about changes in workers' place of residence.

3 Our source for provincial employment data is Mas, M., Perez, F., Uriel, F., and Serrano, L. (1995), Capital humano. Series históricas 1964-1992, Fundación Bancaja.

4 The private physical capital stock data for 1991 (excluding agriculture and fishery) in each region were obtained from Stock de Capital en España y su distribución territorial (1964-2000) published by the Fundación BBVA.

5 Regional non-agricultural unemployment rates were calculated as the average of the quarterly statistics for the last three quarters of 1990 and the first quarter of 1991 in the Encuesta de Población Activa, conducted by the Instituto Nacional de Estadística.

6 A similar reasoning could be made for employment: if territories with high productivity (and wages) attract workers, the causality will be in the opposite direction to that considered here. 
However, we found that the employment variable was not statistically significant at the usual levels.

7 From a theoretical point of view, an income effect operating in the opposite direction may also be expected: when unemployment is high, family income falls making college unaffordable, while teenage children might drop out of school to help support the family. However, empirical evidence does not support this argument (Arkes, 2003; Dalmazo and de Blasio, 2005).

8 All calculations in this section were carried out using STATA's ivreg2 routine.

Detailed results are available from the authors on request.

\section{$\underline{\text { 7. References }}$}

ACEMOGLU, D. (1996) A microfoundation for social increasing returns in human capital accumulation, Quart. J. Econ. 111, 779-804.

ACEMOGLU, D. (1998) Why do new technologies complement skills? Directed technical change and wage inequality, Quart. J. Econ. 113, 1055-89.

AcEmoglu, D. and Angrist, J. (2001) How large are human capital externalities? Evidence from Compulsory Schooling Laws, NBER Macroeconomics Annual 2000, pp. 9-59.

AdSERÀ, A. (2000) Sectoral spillovers and the price of land. A cost analysis, Reg. Sc. And Urb. Econ. $30,565-85$.

Almond, D. (1997) Human capital as a local public good: Evidence from the 1990 US Census, mimeo.

ARKES, J. (2003) Using unemployment rates as instruments to estimate returns to schooling, RAND, mimeo.

BAum,C., Schaffer, M. E., StILlman, S. (2003) Instrumental Variables and GMM: Estimation and Testing, The Stata Journal 3, 1-31.

BeCKer, G. (1964) Human capital, Columbia University Press, New York.

BlanchFlower, D.G.; Oswald, A.J. (1994) Estimating a Wage Curve for Britain 1973-1990, Econ. J., 104, 1025-1043.

Blanchflower, D.G.; Oswald, A.J. (2005), The Wage Curve Reloaded, NBER working paper 11338.

Boyer, R. and Savageau, D. (1985) Places rated almanac, Rand McNally, Chicago. 
Ciccone, A., Hall, R. (1996) Productivity and Density of Economic Activity, Am. Econ. Rev., 86, 54-70.

Dalmazzo, A., De Blasio, G. (2005) Where do human capital externalities end up?, Temi di discusione, 554.

DE LA FuENTE, A. (1996) Economía regional desde una perspectiva neoclásica. De convergencia y otras historias, Rev. Econ. Apl., IV, 10, 5-63.

Fu, S. (2005), Smart Café Cities: Testing Human Capital Externalities in the Boston Metropolitan Area, Boston College Working Paper, 609.

Gorostiaga, A. (1997) ¿Cómo afectan el capital público y el capital humano al crecimiento? Un análisis de las regions españolas en el marco neoclásico, Tesina CEMFI 9701.

Halyna, H. (2004) Private investment in human capital: effect on earnings in Ukraine, Kyiv-Mohyla Academy, mimeo.

HANSEN, L. (1982) Large sample properties of generalized method of moments estimators, Econometrica 50, 1029-1054.

LUCAS, R. (1988) On the mechanics of economic development, J. Mon. Econ. 22, 3-42.

Marshall, A. (1890) Principle of economics, MacMillan, London.

MincER, J. (1974) Schooling, experience and earnings, Columbia University Press, New York.

MORETTI, E. (1998) Social returns to education and human capital externalities: Evidence from cities, Department of Economics, University of Berkeley, mimeo.

NiJKAmp, P. AND PoOt, J. (2005) The last word on the wage curve? A meta-analytic assessment, J. Ec. Surv., 19, 421-50.

PERI, G. (1998) Human capital and productivity in US cities, Bocconi University and IGIER, mimeo.

RAUCH, J. (1993) Productivity gains from geographic concentration of human capital: Evidence from the cities, J. Urb. Econ. 34, 380-400.

RÓDENAS, C. (1994) Emigración y economía en España (1960-1990), Ed. Civitas, Madrid.

RUDD, J. (2000) Empirical evidence on human capital spillovers, Federal Reserve Board, mimeo.

SANROMÁ, E. and RAMOS, R. (1999a) Regional structure of wages and external economies in Spain, in CRAMPtOn, G. (ed.) Regional unemployment, job matching and migration, pp. 183-208, European Research in Regional Science, vol. 9, Pion, London.

SANROMÁ, E. and RAMOS, R. (1999b) Interprovincial wage differences in Spain. A microdata analysis for 1990, Rev. Reg. Res., 19, 35-54.

Schultz, T. (1960) Capital formation by education, J. Pol. Econ. 68, 571-83.

SerRANO, L. (1997) Productividad del trabajo y capital humano en la economía española, Moneda y Crédito, 205, 79-101. 
SERRANO, L. (1999) Capital humano, estructura sectorial y crecimiento en las regiones españolas, Investigaciones Económicas, XXIII, 225-249.

SimÓn, H., RAmOS, R. and SANROMÁ, E. (2006) Collective bargaining and regional wage differences in Spain: An empirical analysis, Appl. Econ., forthcoming.

Simón; H.; Russell, H. (2004) Firms and the Gender Wage Gap: A Cross-National Comparison, Center for Economic Performance Pay Inequalities and Economic Performance Discussion Paper. Smith, A. (1776) The wealth of nations, edition by CANNAN, E. (1908) Random House, New York.

Annex 1. Description of the methodology for constructing the indicator of culture per capita at the provincial level

In line with the methodology proposed for the United States in the Places Rated Almanac (Boyer and Savageau, 1985) we sought to approximate the cultural resources at the territorial level by calculating the number of universities, museums, theatres (films and plays), concert rooms, libraries and art galleries per capita. Data are drawn from the Anuario Estadístico de España for 1990 prepared by the INE (Spanish Institute of Statistics). Each of the partial indicators has been weighted to approximate their specific relevance. The weightings were attributed as follows: universities (20 points), museums ( 8 points), theatres ( 4 points), concert rooms ( 4 points), libraries ( 2 points), art galleries (1 point) and cinemas (1 point). 
Figure 1. Growth rate of the provincial average number of schooling years between 1980 and 1990 and provincial average number of schooling years in 1980




Table 1. Descriptive statistics of schooling levels

\begin{tabular}{lccc} 
& Observations & Average log(wage) & Standard deviation log(wage) \\
\hline 0 years: Illiterate - no studies & 1299 & 13.44 & 0.85 \\
6 years: Primary education & 4756 & 13.70 & 0.71 \\
9 years: Up to secondary education (EGB) or equivalent & 4229 & 13.54 & 0.76 \\
11 years: Technical/Vocational studies - first cycle (FP-1) & 949 & 13.66 & 0.72 \\
12 years: Secondary education (BUP) or equivalent & 1185 & 13.95 & 0.67 \\
13 years: Up to tertiary studies (COU) & 855 & 13.83 & 0.76 \\
14 years: Technical/Vocational studies - second cycle (FP-2) & 986 & 13.86 & 0.71 \\
16 years: Tertiary studies - university first cycle or equivalent & 1514 & 14.25 & 0.59 \\
18 years: Tertiary studies - graduate or equivalent & 1176 & 14.38 & 0.64 \\
\hline
\end{tabular}


Table 2. OLS estimates of the Mincer equation with regional dummies

\begin{tabular}{lcc}
\hline OLS estimates & Coefficient & t-statistic \\
\hline Gender: woman (base category: male) & -0.22 & $-17.92^{* * *}$ \\
Main income provider (base category: not main income provider) & 0.36 & $28.79 * * *$ \\
Years of schooling & 0.06 & $37.36^{* * *}$ \\
Experience & 0.04 & $30.09^{* * *}$ \\
Square of experience & -0.01 & $-21.08^{* * *}$ \\
Part-time (base category: full-time worker) & -0.43 & $-13.94 * * *$ \\
\hline Number of observations & \multicolumn{2}{c}{16949} \\
Adjusted $\mathrm{R}^{2}$ (with intercept and one regional dummy excluded) & \multicolumn{2}{c}{0.43} \\
F-statistic & $157.44 * * *$
\end{tabular}

Industry sector, occupation and regional controls have also been included. In the three cases, the values of the F-test allow us to reject the null hypothesis of joint non-significance at the usual levels: 9.28 for sectors, 28.85 for occupation and 8.45 for regions.

*** Significant variables at the $1 \%$ level. 
Table 3. Average schooling externalities (common regional effects of schooling in the Mincer equation)

\begin{tabular}{|c|c|c|c|c|c|c|c|c|c|c|}
\hline \multirow{3}{*}{$\frac{\text { Estimation method }^{1}}{\text { Intercept }}$} & \multirow{2}{*}{\multicolumn{2}{|c|}{$\begin{array}{c}\text { Model } 1 \\
\mathrm{WLS}^{2}\end{array}$}} & \multirow{2}{*}{\multicolumn{2}{|c|}{$\begin{array}{l}\text { Model } 2 \\
\text { WLS }^{2}\end{array}$}} & \multirow{2}{*}{\multicolumn{2}{|c|}{$\begin{array}{c}\text { Model } 3 \\
\text { WLS }^{2}\end{array}$}} & \multirow{2}{*}{\multicolumn{2}{|c|}{$\begin{array}{c}\text { Model } 4 \\
\mathrm{WLS}^{2}\end{array}$}} & \multirow{2}{*}{\multicolumn{2}{|c|}{$\begin{array}{c}\text { Model } 5 \\
\text { IV }^{3}\end{array}$}} \\
\hline & & & & & & & & & & \\
\hline & 12.01 & $(40.13)^{* * *}$ & 11.72 & $(49.75)^{* * *}$ & 11.61 & $(40.75)^{* * *}$ & 12.18 & $(72.44)^{* * *}$ & 12.02 & $(36.97)^{* * *}$ \\
\hline Provincial average level of schooling & 0.05 & $(3.16)^{* *}$ & 0.05 & $(3.41)^{* *}$ & 0.05 & $(3.37)^{* *}$ & 0.04 & $(2.47)^{* *}$ & 0.05 & $(1.69)^{*}$ \\
\hline Provincial average level of experience & -0.01 & $(-0.28)$ & & & & & & & & \\
\hline Provincial employment $(\log )$ & & & 0.02 & $(1.00)$ & & & & & & \\
\hline Provincial physical capital stock (log) & & & & & 0.02 & $(1.17)$ & & & & \\
\hline Provincial unemployment rate $(\log )$ & & & & & & & -0.05 & $(-2.12)^{* *}$ & -0.04 & $(-1.72)^{*}$ \\
\hline Adjusted $\mathrm{R}^{2}$ & & 0.25 & & 0.27 & & 0.28 & & 0.31 & & 0.29 \\
\hline
\end{tabular}

The number of observations in all models is 50 .

${ }^{1}$ All the estimates were obtained using White's method of correcting for heteroscedasticity.

${ }^{2}$ Estimation by Weighted Least Squares. The weights are obtained from the standard error of the estimates of $\alpha_{j}$ in the restricted Mincer earnings regression.

${ }^{3}$ Estimation by Instrumental Variables. The instruments for the provincial level of schooling are the provincial unemployment rates for those aged 16 to 19 in 1981, the provincial share of residents who were younger than 5 in 1981 and the provincial share of residents between the age of 5 and 10 in 1981 .

* Significant variables at the $10 \%$ level. ** Significant variables at the $5 \%$ level. $* * *$ Significant variables at the $1 \%$ level. 
Table 4. Tests of endogeneity of schooling and the quality of instruments in Model 5 of Table 3

Tests of endogeneity of the provincial level of schooling

H0: Regressor is exogenous

Wu-Hausman F test

0.07

Durbin-Wu-Hausman chi-sq test

0.08

Testing the relevance of the instruments

\begin{tabular}{lc}
\hline F-test on excluded instruments & $8.26^{* * *}$ \\
Partial R & 0.32 \\
Hansen J statistic (overidentification test of all instruments) & $5.76^{* *}$
\end{tabular}

The instruments for the provincial level of schooling are the provincial unemployment rates for those aged 16 to 19 in 1981, the provincial share of residents who were younger than 5 in 1981 and the provincial share of residents between the age of 5 and 10 in 1981.

** Significant variables at the $5 \%$ level. *** Significant variables at the $1 \%$ level. 
Table 5. Average schooling externalities (different regional effects of schooling in the Mincer equation)

\begin{tabular}{|c|c|c|c|c|c|c|c|c|}
\hline \multirow{3}{*}{$\frac{\text { Estimation method }^{1}}{\text { Intercept }}$} & \multirow{2}{*}{\multicolumn{2}{|c|}{$\begin{array}{l}\text { Model } 1 \\
\text { WLS }^{2}\end{array}$}} & \multirow{2}{*}{\multicolumn{2}{|c|}{$\begin{array}{c}\text { Model } 2 \\
\text { WLS }^{2}\end{array}$}} & \multirow{2}{*}{\multicolumn{2}{|c|}{$\begin{array}{c}\text { Model } 3 \\
\text { WLS }^{2}\end{array}$}} & \multirow{2}{*}{\multicolumn{2}{|c|}{$\begin{array}{c}\text { Model } 4 \\
\text { WLS }^{2}\end{array}$}} \\
\hline & & & & & & & & \\
\hline & 12.44 & $(22.85)^{* * *}$ & 11.06 & $(34.44)^{* * *}$ & 10.80 & $(29.90)^{* * *}$ & 12.08 & $(39.97)^{* * *}$ \\
\hline Provincial average level of schooling & 0.06 & $(2.13)^{* *}$ & 0.07 & $(2.99)^{* * *}$ & 0.07 & $(3.37)^{* *}$ & 0.05 & $(1.88)^{*}$ \\
\hline Provincial average level of experience & -0.03 & $(-1.32)$ & & & & & & \\
\hline Provincial employment (log) & & & 0.06 & $(2.99)^{* * *}$ & & & & \\
\hline Provincial physical capital stock (log) & & & & & 0.06 & $(3.34)^{* * *}$ & & \\
\hline Provincial unemployment rate $(\log )$ & & & & & & & -0.06 & $(-1.71)^{*}$ \\
\hline$\overline{\text { Adjusted } \mathrm{R}^{2}}$ & & .22 & & 0.30 & & 0.29 & & 0.21 \\
\hline
\end{tabular}

The number of observations in all models is 50 .

${ }^{1}$ All the estimates have been obtained using White's method of correcting for heteroscedasticity.

${ }^{2}$ Estimation by Weighted Least Squares. The weights are obtained from the standard error of the estimates of $\alpha_{j}$ in the unrestricted Mincer earnings regression..

* Significant variables at the $10 \%$ level. ** Significant variables at the $5 \%$ level. *** Significant variables at the $1 \%$ level. 
Table 5. Average schooling externalities (different regional effects of schooling in the Mincer equation) (continuation)

\begin{tabular}{|c|c|c|c|c|c|c|c|c|}
\hline \multirow{3}{*}{$\frac{\text { Estimation method }^{1}}{\text { Intercept }}$} & \multirow{2}{*}{\multicolumn{2}{|c|}{$\begin{array}{c}\text { Model } 5 \\
\text { WLS }^{2}\end{array}$}} & \multirow{2}{*}{\multicolumn{2}{|c|}{$\begin{array}{c}\text { Model } 6 \\
\text { WLS }^{2}\end{array}$}} & \multirow{2}{*}{\multicolumn{2}{|c|}{$\begin{array}{c}\text { Model } 7 \\
\text { IV }^{3}\end{array}$}} & \multirow{2}{*}{\multicolumn{2}{|c|}{$\begin{array}{c}\text { Model } 8 \\
\text { IV }^{3}\end{array}$}} \\
\hline & & & & & & & & \\
\hline & 11.37 & $(36.78)^{* * *}$ & 11.07 & $(31.57)^{* * *}$ & 11.09 & $(15.69)^{* * *}$ & 10.68 & $(14.32)^{* * *}$ \\
\hline Provincial average level of schooling & 0.05 & $(2.06)^{* *}$ & 0.05 & $(1.96)^{* *}$ & 0.07 & $(1.01)$ & 0.07 & $(0.85)$ \\
\hline \multicolumn{9}{|l|}{ Provincial average level of experience } \\
\hline Provincial employment $(\log )$ & 0.07 & $(3.26)^{* * *}$ & & & 0.04 & $(1.12)$ & & \\
\hline Provincial physical capital stock (log) & & & 0.07 & $(3.57)^{* * *}$ & & & 0.06 & $(2.78)^{* * *}$ \\
\hline Provincial unemployment rate $(\log )$ & -0.10 & $(-1.97)^{* *}$ & -0.09 & $(-1.93)^{*}$ & -0.07 & $(-1.71)^{*}$ & -0.05 & $(-1.85)^{*}$ \\
\hline$\overline{\text { Adjusted } \mathrm{R}^{2}}$ & & 0.36 & & 0.35 & & 0.14 & & 0.19 \\
\hline
\end{tabular}

The number of observations in all models is 50 .

${ }^{1}$ All the estimates have been obtained using White's method of correcting for heteroscedasticity.

${ }^{2}$ Estimation by Weighted Least Squares. The weights are obtained from the standard error of the estimates of $\alpha_{j}$ in the equation (1).

${ }^{3}$ Estimation by Instrumental Variables. The instruments in model 9 are the provincial unemployment rates for those aged 16 to 19 in 1981, the provincial share of residents who were younger than 5 in 1981 and the provincial share of residents between the ages of 5 and 10 in 1981. The instruments in model 8 are the same as those in model 9 plus a culture per capita indicator (see annex 2) and a dummy variable which takes a value of 1 for provinces with a coastline and zero for all those without The instruments for the provincial level of schooling are the provincial unemployment rates for those aged 16 to 19 in 1981, the provincial share of residents who were younger than 5 in 1981 and the provincial share of residents between the age of 5 and 10 in 1981.

* Significant variables at the $10 \%$ level. ** Significant variables at the 5\% level. *** Significant variables at the $1 \%$ level. 